\title{
Ivan the Terrible and Philip the Prudent
}

\author{
Sergei Bogatyrev \\ Associate Professor in Early Russian History, School of Slavonic and East \\ European Studies, University College London, London, United Kingdom \\ s.bogatyrev@ucl.ac.uk
}

\begin{abstract}
This paper discusses the comparative aspect of Charles Halperin's biography of Ivan the Terrible. In his book, Halperin reassesses Michael Cherniavsky's view of Ivan the Terrible as a Renaissance prince by noting that Cherniavsky overestimated the importance of Moscow-the Third Rome theory and used unreliable later sources. In Russian scholarship, according to Halperin, comparative works on Ivan IV have been marred with nationalism. One should also add here the negative impact of vulgar Marxism on Soviet comparative studies of Ivan IV. Nevertheless, a comparative approach to Ivan the Terrible is still viable because, as Halperin astutely notes, the first Russian tsar "resembled his contemporaries among foreign rulers more than he did his Muscovite predecessors or successors." In this article I apply Halperin's comparative methodology to Ivan IV the Terrible and Philip II the Prudent of Spain. What Ivan and Philip had in common was not Renaissance ideas but intensive religious beliefs. The paper examines the foreign and domestic policies of both monarchs, as well as their contemporary visual representations from the perspectives of their religious views. Ivan's and Philip's preoccupation with their countryside residences, Aleksandrovskaia Sloboda and the Escorial respectively, is also discussed in the context of the rulers' intensive religiosity. Despite their different confessions, Ivan IV and Philip II were driven by aspirations for what they saw as original, simple, correct Christianity.
\end{abstract}

\section{Keywords}

Ivan the Terrible - Philip II of Spain - religiosity - Aleksandrovskaia Sloboda - the Escorial - Charles Halperin - Michael Cherniavsky - comparative analysis - Jenkinson's map of Muscovy 
I would like to start with a personal note explaining how I became interested in Ivan the Terrible. In high school, I was fascinated with the history of the Spanish Armada and the man who sent it to England, Philip II, king of Spain (1556-98), where he was known as Philip the Prudent, and also king of England (1554-58) and Portugal (1580-98). My inspiration largely came from Les trésors de l'Armada by the Belgian underwater archaeologist Robert Sténuit. ${ }^{1}$ When I started reading history at the Institute for History and Archives in Moscow, it became clear that that was the wrong place for doing Spanish history. But it turned out that a Russian contemporary of Philip II, Ivan the Terrible, was in many respects similar to the Spanish king. Both rulers had strong views, which they pursued by all available means, both had troublesome relationships with their sons, both appeared in black apparels, and both sought solitude in countryside residences. There was an aura of dark glamour around both monarchs. So, for me it was Ivan now.

The above hopefully explains why I was pleased to see Philip II appearing on many pages of Charles Halperin's Ivan the Terrible: Free to Reward and Free to Punish. He points out that Ivan and Philip started making political input at the age of sixteen (44). ${ }^{2}$ Both rulers resorted to violence, though Philip used lethal repression against open opposition, while there is no serious evidence that anyone challenged Ivan's power in Muscovy (235). Halperin also mentions the tragic fates of Ivan's and Philip's sons, Ivan Ivanovich and Don Carlos (251). Both monarchs could treat individual monks very harshly, though Ivan never aspired to control the church to the extent the Spanish king did $(45,190)$.

Halperin also notes significant, often surprising differences. Contrary to Philip, who had no standing army and had to import weapon, including guns, Ivan commanded the regular musketeer infantry and domestically manufactured artillery pieces (145). Despite his allegedly unlimited power, Ivan proved to be less obstinate in his military adventures in Livonia than Philip in the Netherlands and France (241). Ivan and Philip also differed in their approach to security. Whether Ivan imagined threats or not (he probably did), security was one of his main concerns. At the same time, Philip neglected bodyguards (259).

Halperin discusses Philip II in the context of a broader comparative study of Ivan IV. Halperin's book provides a new perspective on the place of the first Russian tsar among other sixteenth-century monarchs. A comparative approach to Ivan was pioneered in the influential essay of Michael Cherniavsky

1 Rober Steniui, Sokrovishcha Nepobedimoi Armady (Moscow: Mysl', 1979), first published in French in 1971.

2 Here and below references to Charles J. Halperin, Ivan the Terrible: Free to Reward and Free to Punish (Pittsburgh, Pa.: University of Pittsburgh Press, 2019) are given with page numbers in brackets in the main text. 
about Ivan as a Renaissance prince. According to Cherniavsky, Ivan fused the idea of the ruler who used terror to provide justice and the idea of the free personality, who was above human and divine law. ${ }^{3}$

Cherniavsky's comparative analysis is not free from internal problems. As Halperin demonstrates, Cherniavsky overestimated the importance of Moscowthe Third Rome theory and used later and unreliable sources (212-213). Due to these and other oversights in Cherniavsky's work (see below), Western historians became hesitant to draw parallels between Ivan and other sixteenthcentury rulers. After Cherniavsky, comparative analysis of Ivan became deliberately anachronistic: the first Russian tsar was studied from the perspective of the Carolingian Renaissance (Daniel Rowland) or thirteenth-century Mongol rulership when the khan was at the zenith of his power (Donald Ostrowski). ${ }^{4}$

In Russian scholarship, comparative studies of Ivan IV have been marred with vulgar Marxism and nationalism. For example, in his discussion of Ivan's terror, the Soviet historian A. A. Zimin provided a whole list of sixteenth-century Western monarchs, including Philip II, whom the historian described, with Marxist disdain for feudal exploiters, as moral degenerates. According to Zimin, Ivan did not differ from these rulers who masked their cruelty with hypocrisy and religiosity. Modern nationalistic authors substitute Marxism with clericalism, but they also seek to normalize Ivan's terror with references to Philip II and other European rulers (Viacheslav Shaposhnik). ${ }^{5}$

Halperin's comparison is more sophisticated, as he refrains from labelling and fully appreciates the importance of religion in early modern politics. Halperin clearly demonstrates that comparative studies of Ivan are possible without subscribing to the Marxist or nationalist agenda. Comparison does not make Ivan better or worse: "If Ivan was no worse than his contemporaries, neither was he any better. He resembled his contemporaries among foreign rulers more than he did his Muscovite predecessors or successors" (5).

Ivan the Terrible: Free to Reward and Free to Punish continues the line of comparative inquiry introduced by Cherniavsky. Halperin explains that by describing Ivan as a Renaissance prince, Cherniavsky did not mean to imply

3 Michael Cherniavsky, "Ivan the Terrible as Renaissance Prince," Slavic Review, 27 (1968), 2: 195-211.

4 Daniel Rowland, "Ivan the Terrible as a Carolingian Renaissance Prince, " Harvard Ukrainian Studies, 19 (1995): 594-6o6; Donald Ostrowski, Muscovy and the Mongols: Cross-Cultural Influences on the Steppe Frontier, 1304-1589 (Cambridge: Cambridge University Press, 1998), 180-181, 188-198.

5 A. A. Zimin, Vkanun groznykh potriasenii: Predposylki pervoi krest'ianskoi voiny v Rossii (Moscow: Mysl', 1986), 102; Viacheslav Shaposhnik, "Ivan the Terrible: The First Russian Tsar," in Ivan Vasil'evich Receives a Profession: Studies of Ivan the Terrible in Post-Soviet Russia, ed. Sergei Bogatyrev (Russian Studies in History, 53 [2014], no. 1), 78-79 (first published in Russian in 2006). 
that Ivan patronized Renaissance humanism or art. Rather, the tsar's self-image as a Renaissance prince resulted from parallel development in the Renaissance and Ivan's conceptions of rule rather than from Renaissance influence (211212). Halperin is correct when he leaves the Western Renaissance out of the equation. There was of course Renaissance influence in Muscovite architecture, chronicle miniatures, and book ornament. But these Renaissance elements underwent deep transformation in the context of Muscovite culture and lost their original Renaissance message. ${ }^{6}$ I would probably go even further by arguing that it is misleading to speak of Ivan as a Renaissance prince because the Renaissance is a loaded concept which obscures various, often conflicting views of the role of religion in politics. In his talk at the 2019 Convention of the Association for Slavic, East European, and Eurasian Studies, Halperin noted that Cherniavsky called Ivan a Renaissance prince because his views were similar to those of Machiavelli. Cherniavsky's parallels are superficial. According to Alison Brown, "there is little evidence that Machiavelli believed in Christian revelation or even in the special authority accorded to religious states and holy men. His writings provide instead a remarkably consistent account of a world in which religion played a supporting but subordinate role in the essential art of politics." 7 This view would be more typical of Vladimir Putin than Ivan the Terrible, who, as Halperin notes, like other mortals acknowledged his subordination to divine law (213).

Still, Halperin is correct in drawing out attention to Cherniavsky's comparative methodology. But we need to change the focus of our comparative analysis. If Ivan and contemporary Western monarchs had any common background, it was Christianity, not the Renaissance. Not all sixteenth-century Western politicians were as cynical about religion as Machiavelli. This is why in this paper I will try to apply Halperin's comparative approach to the religious practices of Ivan IV and Philip II. One of the advantages of a comparative study of contemporary monarchs is that it permits both a concrete and typological analysis. The first part of this paper will revisit the history of contacts between Ivan and Philip and, as far as the sources permit, their mutual perception. In the second part I will put these contacts in a broader perspective of a typological comparison of religious strategies employed by the two monarchs.

6 See M. L. Ivanov, Litsevoi letopisnyi svod, Zhitie Nikoly i Egorovskii sbornik: Opyt kompleksnogo izucheniia (Moscow, AKTEON, 2017), 22, 28, 124-126, 149-150; Iu. N. Zvezdina, Skul'pturnoe ubranstvo kremlevskikh soborov. Puti intepretatsii renessansnogo dekora (Moscow: Gos. istoriko-kul'turnyi muzei-zapovednik “Moskovskii Kreml',"(cf note 38) 2017) and, despite its late-Stalinist nationalistic tone, A. A. Sidorov, Drevnerusskaia knizhnaia graviura (Moscow: Izdatel'stvo AN sssR, 1951).

7 Alison Brown, "Philosophy and Religion in Machiavelli," in The Cambridge Companion to Machiavelli, ed. John M. Najemy (Cambridge: Cambridge University Press, 2010), 167. 


\section{Diplomacy and Representation}

Ivan and Philip communicated via diplomatic and trade agents. In his capacity of king-consort of England, Philip II and his wife, Mary I Tudor sent a mission to Ivan to negotiate English trade privileges in Muscovy, promising reciprocal privileges for Russian merchants, in 1555 . Their letter to Ivan was written in Greek, Polish and Italian, a sign that the English had no experts in East Slavic and were uncertain as to what other languages the Muscovite court would understand. To project the power of the royal couple in the far lying Muscovy, one of the English ships carrying the delegation had the pretentious name Philip and Mary. ${ }^{8}$

Together with Mary, Philip also received the first Russian ambassador to England, Osip Nepeia, in London in 1557. Despite suffering a shipwreck on the Scottish coast, Nepeia brought to Philip and Mary what they later described as "loving and freendly lettres" from Ivan. In their response, which was sent with Nepeia in April 1557, the royal couple confirmed generous, though not entirely reciprocal rights for Russian merchants in England and committed themselves to sending artisans and craftsmen to Moscow. On a more personal level, Philip and Mary undoubtedly pleased Ivan when they addressed him with the title of emperor. This was the closest Western equivalent to Ivan's new title of tsar, which he eagerly promoted in diplomatic relations. Muscovite diplomats subsequently evoked Philip's letters to Ivan as evidence of international recognition of Ivan's title of tsar during negotiations with the Poles. ${ }^{9}$ At the same time, in their 1557 letter, the royal couple misnamed the Russian tsar Vasilii (Vuassilia), though they got Ivan's name right in their previous letter (1555). The king and the queen sent with Nepeia a peculiar set of gifts for the tsar: pieces of fine cloth, a pair of coats of mail (brigandines) with a helmet (morion), and "a male and female lions." ${ }^{10}$ By presenting cloth, which was of course the main item of English export, the royal couple sought to promote English commercial interests in Muscovy. The gifts of armour and lions were more exotic than

8 T. S. Willan, The Early History of the Russia Company, 1553-1603 (Manchester: Manchester University Press, 1956), 10. Philip's and Mary's letter from 1 April 1555: Richard Hakluyt, ed., The Principal Navigations, Voyages, Traffiques and Discoveries of the English Nation, 2 (Glasgow: James MacLehose and Sons, 1903), 278-281.

9 A. L. Khoroshkevich, Rossiia v sisteme mezhdunarodnykh otnoshenii serediny XVI veka (Moscow: Drevlekhranilishche, 2003), 176, 370.

10 Willan, Early History, 16; Samuel H. Baron, "Osip Nepea and the Opening of Anglo-Russian Commercial Relations," Oxford Slavonic Papers, New Series, 11 (1978): 52-53, 59-6o; Philip's and Mary's letter to Ivan from 1557: Sobranie gosudarstvennykh gramot i dogovorov..., 5 (Moscow: E. Lissner and Iu. Roman, 1894), 134-140 (nos. 113, 114). 
sophisticated, especially if one considers that brigandines and morions were usually worn by foot soldiers rather than by aristocratic cavalrymen (Philip himself often appears in portraits wearing plate armour of exquisite quality). The presented armour and lions referred to the masculine qualities of a monarch, evoking the idea of military strength and power which tamed even wild mighty beasts. Ivan was apparently pleased with the royal gifts, as a list of these gifts was included in the Nikonian chronicle, which usually ignores such details of diplomatic relations. Furthermore, the Book of Degrees of the Royal Genealogy (Stepennaia kniga, 156os) proudly lists the gifts received from Philip and Mary, including a lion cub, which is not mentioned in other sources (was the cub born already in Muscovy?), and notes that the royal gifts included other things fitting the tsar's dignity. ${ }^{11}$

Generally, Ivan IV's chroniclers held Philip II in high esteem. In Muscovite narrative accounts of Anglo-Russian relations in the 1550s, Philip appears as rightful king of England while Mary Tudor, despite her English background, occupies a subordinated position. Her name is either in the second place after Philip's and or not mentioned at all. This manly view of politics was hardly specifically Muscovite, as the above-mentioned English royal letters to Ivan also put Philip's name before Mary's. According to Muscovite chroniclers, Philip was also important as a son of Emperor Charles $\mathrm{v}$ (tsesareva Karlosova syn). ${ }^{12}$ This note is remarkable because the English royal correspondence that came to Moscow did not mention Philip's genealogy. Ivan's bookmen did their homework when preparing the chronicle accounts of Philip II's relations with Russia. From the late 1560 on, the Muscovite court entertained the idea of an antiTurkish coalition with the Habsburgs with Philip playing a major part in this project. $^{13}$

Muscovite visual representations of Philip II developed his image of a strong male ruler. Philip appears in two miniatures in an illustrated chronicle created at Ivan IV's residence of Aleksandrovskaia Sloboda in the late 156os and the 1570 (Illustrated Chronicle Compilation, Litsevoi letopisnyi svod). The first miniature illustrates diplomatic contacts between England and Russia in 1555

11 N. N. Pokrovskii, G. D. Lenhoff, eds., Stepennaia kniga tsarskogo rodosloviia po drevneishim spiskam (hereafter SK), 2 (Moscow: Iazyki slavianskikh kul'tur, 2008), 389.

12 Polnoe sobranie russkikh letopisei (hereafter PSRL), 13, 1st half (St. Petersburg: Tipografiia I. N. Skorokhodova, 1904), 262, 270, 285-286; SK, 2: 389; Khoroshkevich, Rossiia, 169 note 181.

13 B. N. Floria, Russko-pol'skie otnosheniia i politicheskoe razvitie Vostochnoi Evropy vo vtoroi polovine XVI - nachale XVII v. (Moscow: Nauka, 1978), 65, 158. 


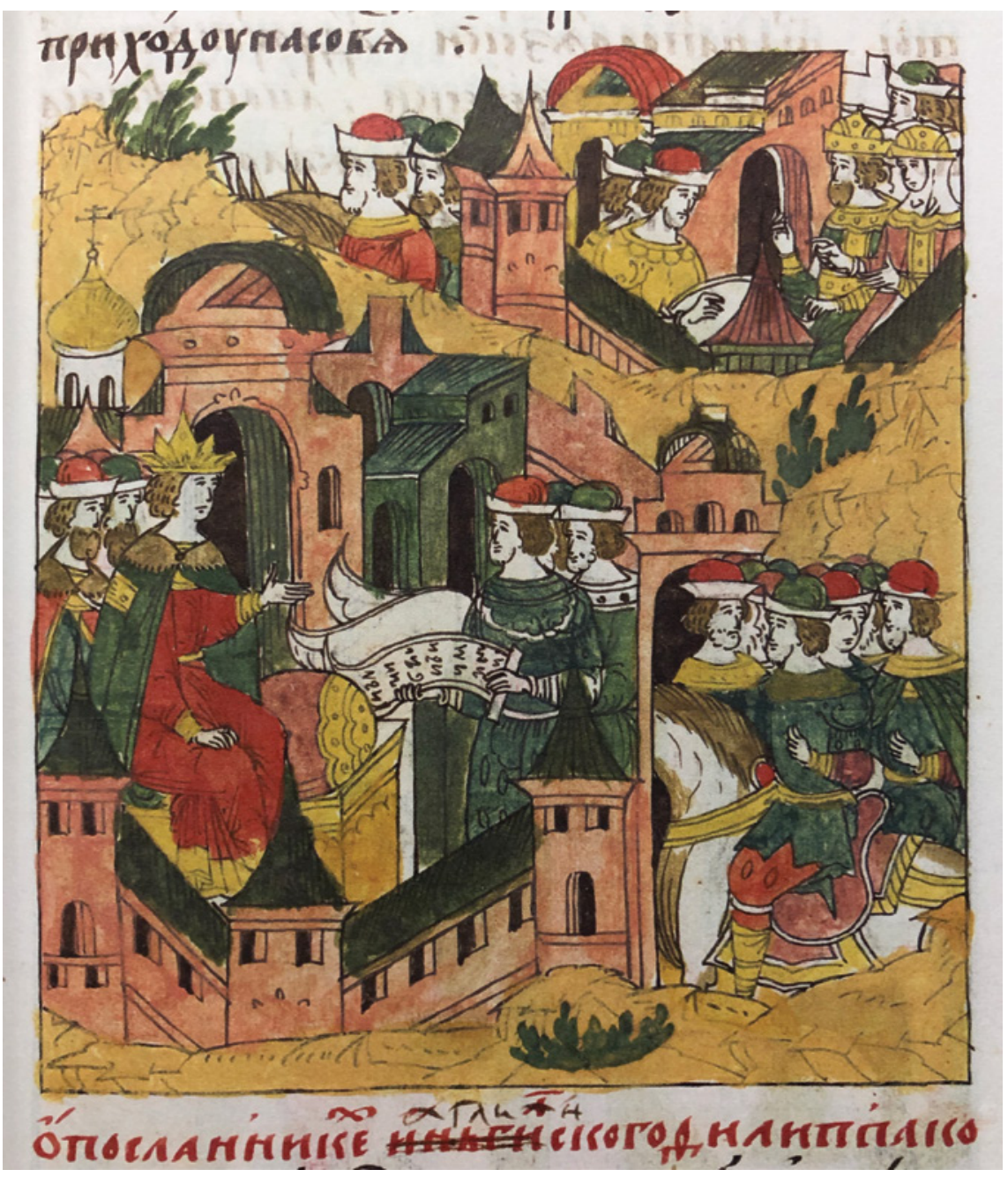

FIGURE 1 Philip II and Mary Tudor send drop an envoys to Ivan IV in 1555 (Illustrated Chronicle Compilation)

(Fig. 1). ${ }^{14}$ The royal couple, with Philip depicted ahead of Mary, dispatch their delegation from London in the upper right corner of the miniature. In the lower part of the illustration Ivan receives the English agents in Moscow, which is marked with an Orthodox church (otherwise the architecture of both cities is

14 Litsevoi letopisnyi svod XVI veka: Russkaia letopisnaia istoriia: Kniga 22, 1553-1557 (Moscow: AKTEON, 2011), 239. Online edition: http://www.sterligoff.ru/books/Rus_Kniga\%2022.pdf (accessed 23 December 2019). 
virtually the same). The English envoys give the tsar three documents, apparently the above-mentioned 1555 royal letter which was prepared in three copies in different languages.

All persons shown in the miniature have identical conventional faces; different personages are marked with symbols like headgear and beards. Philip's royal status is indicated with a peculiar yellow (presumably golden) crown; Mary wears a crown of different design. Ivan has a pointed crown which refers to his title of tsar. ${ }^{15}$ Unlike the bearded figure of Philip, Ivan appears beardless. In the chronicle miniatures, beards usually indicate maturity or advanced age. However, Philip, who was born in 1527, was only three years older than Ivan. Apparently, Philip's beard is part of a general representation of a king from the powerful Habsburg dynasty: a mature married man invested with royal regalia. At the same time, Ivan's beardless evoked the idea that he was "young in years..., but old in wisdom:" even if the Russian ruler had only recently assumed the title of tsar and married in 1547, now he was on par with other Christian rulers, including Philip. ${ }^{16}$ Accidently, the miniature shows the English agents travelling to Russia in 1555 on horseback, but not by ship. The illustration thus makes a false impression that one can take a trip from London to Moscow by land only because the artist mechanically followed the chronicle text which does not mention any sea travel.

Sea with ships, both afloat and sinking, does appear in the second miniature which shows Nepeia's mission to England in 1557 (Fig. 2), including his troublesome sea voyage to the British isles (the middle part of the miniature), his reception by Philip and Mary in London (lower part) and return with the abovementioned royal gifts to Moscow (upper part). ${ }^{17}$ The images of English and Muscovite royalty generally follow the previous miniature, with the only exception of Mary's crown, which looks now exactly like Ivan's crown (this pattern of female royal headgear is typical of Muscovite art). The scene of Ivan receiving Nepeia in Moscow features representations of gifts sent by Philip and Mary, including the pair of lions.

We can now turn to images of Ivan IV that were available to Philip II. His personal possessions included three copies of Abraham Ortelius' Theatrum Orbis Terrarum, which is usually seen as the first modern atlas. Ortelius was Philip's cartographer, hence the dedication of Theatrum to the Spanish king. ${ }^{18}$

15 On the symbolism of headgear in the chronicle miniatures, see Sergei Bogatyrev, "Three Takes on One Legend: Polyphony in Muscovite Court Culture," Kritika: Explorations in Russian and Eurasian History, 19 (2018), 1: 31, 34-36.

16 Cf. PSRL, 5, issue 1 (Moscow: Iazyki slavianskoi kul'tury, 2003), 110.

17 Litsevoi letopisnyi svod, 22: 429.

18 Geoffrey Parker, "Maps and Ministers: The Spanish Habsburgs," in Monarchs, Ministers and Maps: The Emergence of Cartography as a Tool of Government in Early Modern Europe, 


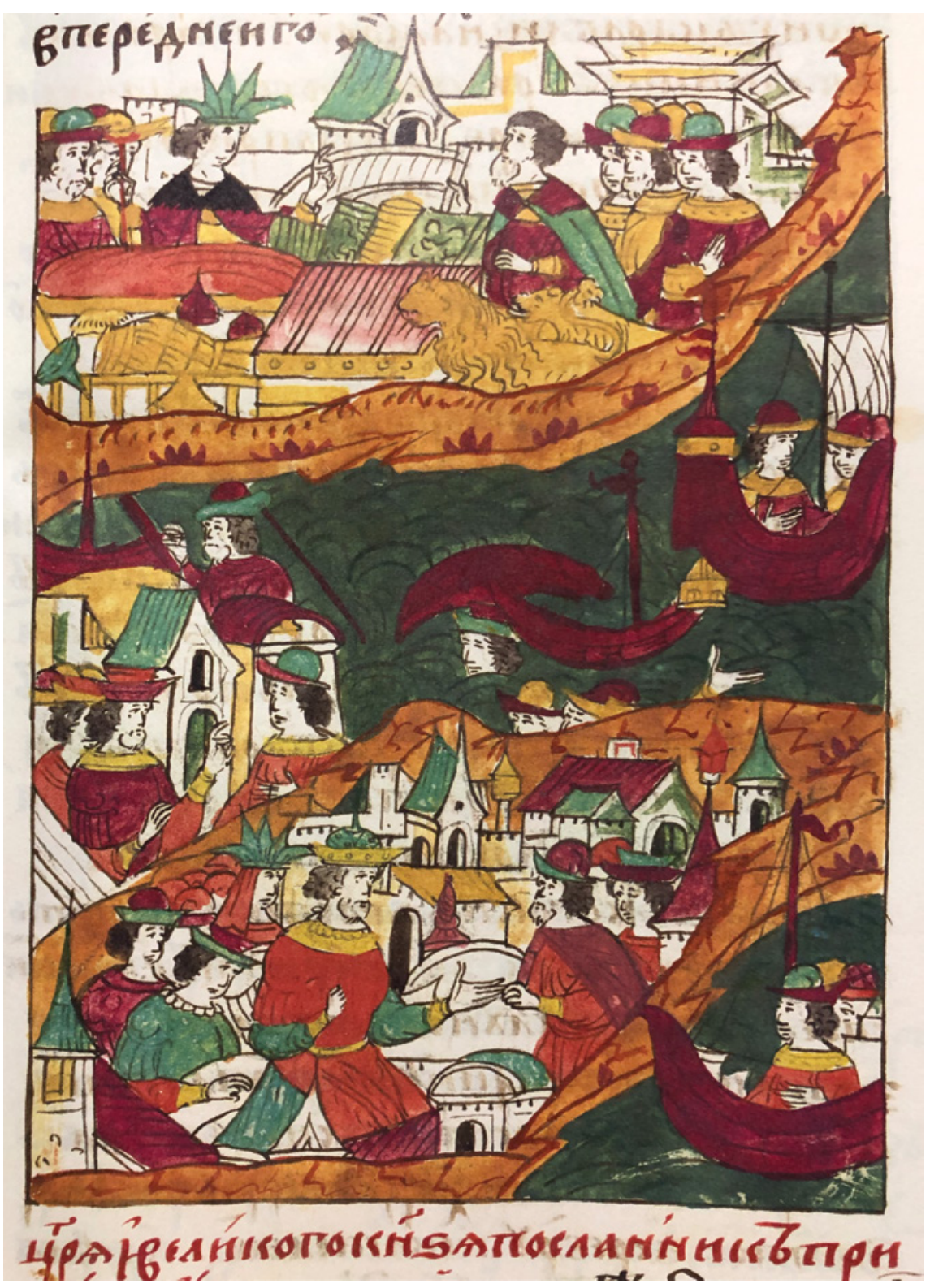

FIGURE 2 The mission of Ivan IV's envoy Osip Nepeia to Philip II and Mary Tudor in 1557 (Illustrated Chronicle Compilation)

ed. David Buisseret (Chicago, London: University of Chicago Press, 1992), 124, 127; Tine Luk Meganck, Erudite Eyes: Friendship, Art and Erudition in the Network of Abraham Ortelius (1527-1598) (Leiden, Boston: Brill, 2017), 29. The first edition of Theatrum appeared in 
According to the courtier Jehan Lhermite, framed maps from Ortelius' Theatrum also hung in the Escorial's Galería de Paseo where Philip promenaded with his children at sunset. The maps, which represented different parts of the world, visualised Philip II's aspiration for universal domination. ${ }^{19}$

Russia appears in several maps from Ortelius' Theatrum, either partially (in the maps of Persia, Asiae Nova Descriptio, Poland) or in full in the famous Jenkinson map of Muscovy which Ortelius included in his atlas (all these maps are hanging now in the Galería de Paseo). Jenkinson's map, which features an image of Ivan IV ("Ivan Vasil'evich, great emperor of Rus'), is particularly important for a study of visual representations of the first Russian tsar in Western cartography. The image of Ivan underwent deep transformation in different versions of the Jenkinson map. Both the original map and its reworked variant in Ortelius' collection feature representations of Ivan IV in the upper left corner of the map. A standard feature of Renaissance cartography, this visual device indicated that any particular country belonged to one monarch. ${ }^{20}$

According to Krystyna Szykuła, the original Jenkinson map was compiled between 1562 and ca. 1567. It has survived in a single copy which is now in the library of the University of Wroclaw. The artist of Jenkinson's map (Johannes de Schille or Nicolaus Reinoldus) depicted Ivan IV sitting on a gorgeous Renaissance throne with a high back (Fig. 3). ${ }^{21}$ This representation of Ivan IV capitalises on royal images that can be found in Olaus Magnus' Carta Marina

1570. The Royal Library at the Escorial currently holds three sets of Ortelius' Theatrum, two editions from the time of Philip II (1570 and 1573) and one from a later period (1601).

19 Jehan Lhermite, Le Passetemps, ed. E. Ouverleaux and J. Petit, 2 (Genève: Slatkine Reprints, 1971), 68-70; George Kubler, Building the Escorial (Princeton, N.J.: Princeton University Press, 1982), 88; Jean-François Lasnier and others, The Royal Monastery of San Lorenzo de El Escorial ([Paris, Madrid]: Connaissance des Arts, Patrimonio Nacional and Ediciones El Viso, [2012]), 50 (section by Jérôme Coignard). The original set of Ortelius' maps from the Galería de Paseo has been lost. Currently the gallery is decorated with Ortelius' maps which were acquired in the $1950 \mathrm{os}$.

20 [E. Delmar Morgan], "Introduction," in Early Voyages and Travels to Russia and Persia by Anthony Jenkinson and other Englishmen, ed. Morgan, C. H. Coote, 1 (New York: Burt Franklin, n.d., first published by The Hakluyt Society, 1886), cxxi.

21 Online publication: https:/www.bibliotekacyfrowa.pl/dlibra/publication/40164/edition/ 40845/content (accessed 13 December 2019). On the Jenkinson map and its impact on cartography, see Samuel H. Baron, "The Lost Jenkinson Map of Russia (1562) Recovered, Redated and Retitled," Terrae Incognitae, 25 (1993), 1: 53-65. Krystyna Szykuła, "Anthony Jenkinson's Unique Wall Map of Russia (1562) and Its Influence on European Cartography," Belgeo [Online], 3-4 (2008): 325-340 (hard copy pagination), 1-17 (online copy pagination), http://journals.openedition.org/belgeo/8827 (accessed 13 December 2019); Valerie Kivelson, "Early Mapping: The Tsardom in Manuscript," in Information and Empire: Mechanisms of Communication in Russia, 1600-1850, ed. Simon Franklin and Katherine Bowers (Cambridge: Open Book Publishers, 2017), 54; Katharina N. Piechocki, Cartographic 


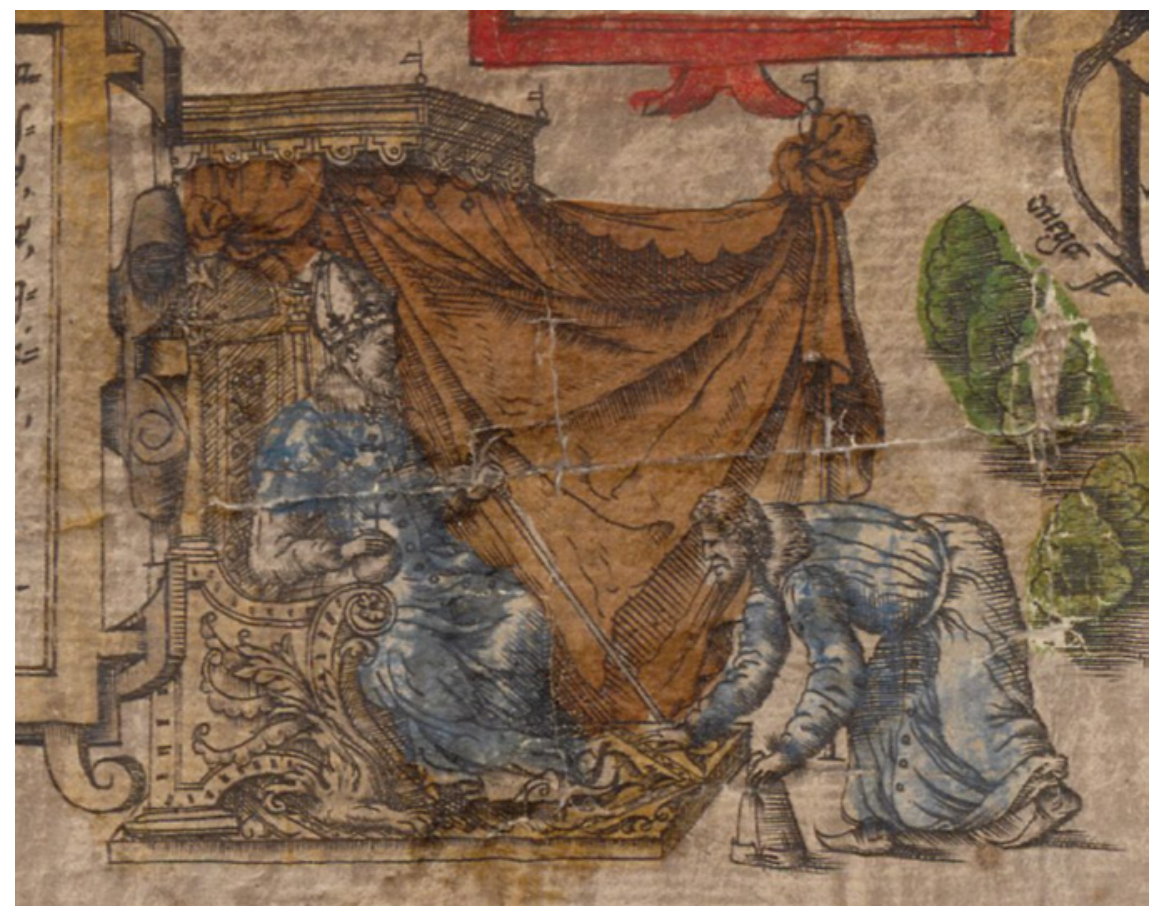

FIGURE 3 Ivan IV (original Jenkinson map, 1562 - ca. 1567)

(1539). Magnus' map features sitting figures of Western kings with sceptres and orbs with crosses in their hands (see Fig. 4). ${ }^{22}$ The Carta Marina also includes an image of the grand prince of Muscovy shown as a bearded man in a plain conical cap, with a flanged mace in one raised hand and another gripping the hilt of his sabre (Fig. 5). This representation of the armed Muscovite prince emphasises his aggression, resonating with battle scenes between Russians and Swedes in other parts of the map. In the second edition of Magnus' Carta Marina (1572), the representation of the Muscovite prince is less militant and

Humanism: The Making of Early Modern Europe (Chicago: The University of Chicago Press, 2019), 104-106.

22 Online publication of Magnus' Carta Marina (1539): http://www.alvin-portal.org/alvin/ imageViewer.jsf?dsId=ATTACHMENT-ooo1\&pid=alvin-record\%3A88495\&dswid=-1177 (accessed 14 December 2019). On Magnus' map, see Leena Miekkavaara, "Unknown Europe: The Mapping of the Northern Countries by Olaus Magnus in 1539," Belgeo, 3-4 (2008): 307-324 (hard copy pagination), https://journals.openedition.org/belgeo/7677 (accessed 23 December 2019). 


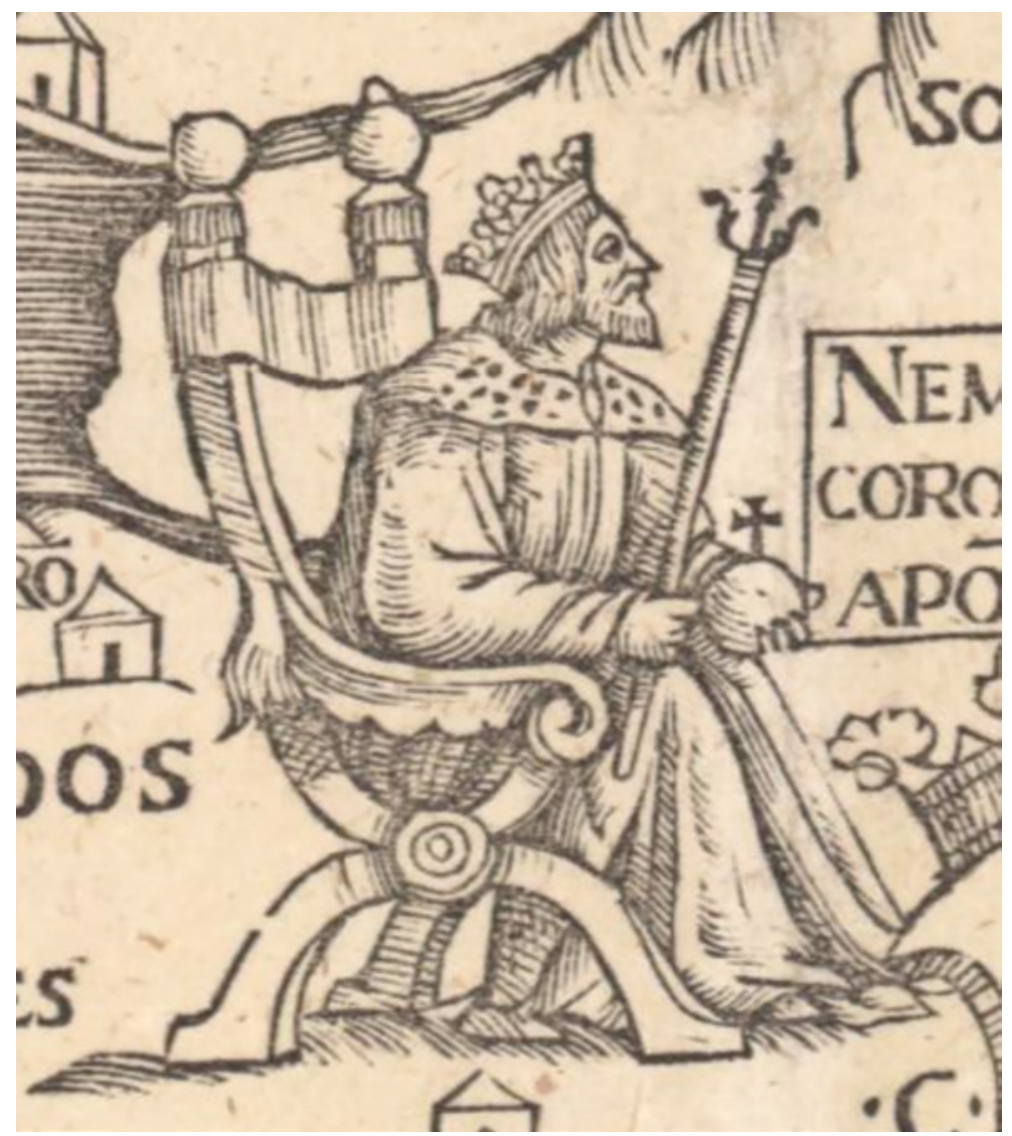

FIGURE 4 King of Norway (Olaus Magnus' Carta Marina, 1539)

more regnal. He still has his mace, but his sabre has been substituted with an orb, though, unlike other royal images in the map, his orb has no cross (Fig. 6). ${ }^{23}$

A similar set of Western regalia appears in the image of Ivan in the original Jenkinson map (now the orb is topped with a cross). It is hard to say which edition of Magnus' Carta Marina became a source for the royal image in the English map. Chronologically, Jenkinson's map is later than the first edition of the Carta Marina (1539) and predates its second edition (1572). However, the dating of early modern maps is often uncertain. One cannot exclude that the second edition of the Carta Marina circulated before its official date of publication (1572) and was available to the creator of the Jenkinson map who worked in the 156os. Alternatively, the artists of the original Jenkinson map and the

23 The 1572 edition of Magnus' map: https://kansalliskirjasto.finna.fi/Record/doria.10024_ 147788 (accessed 14 December 2019). 


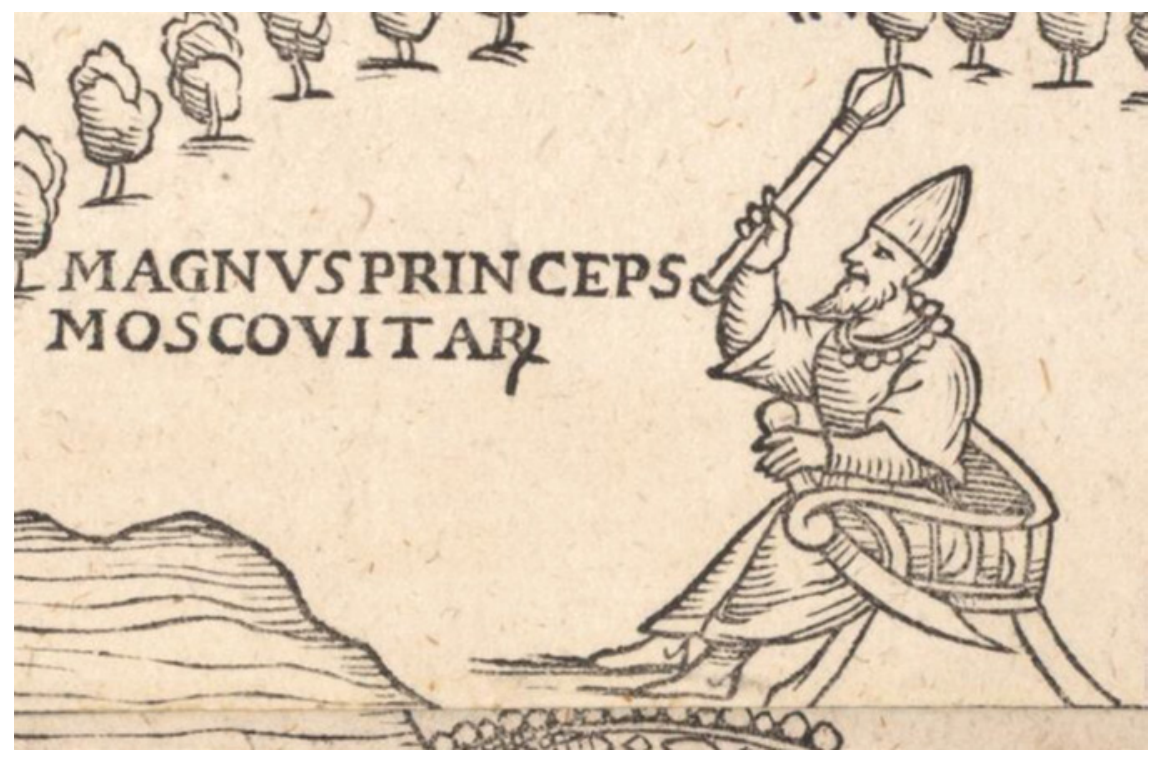

FIGURE 5 Great Prince of Muscovy (Olaus Magnus' Carta Marina, 1539)

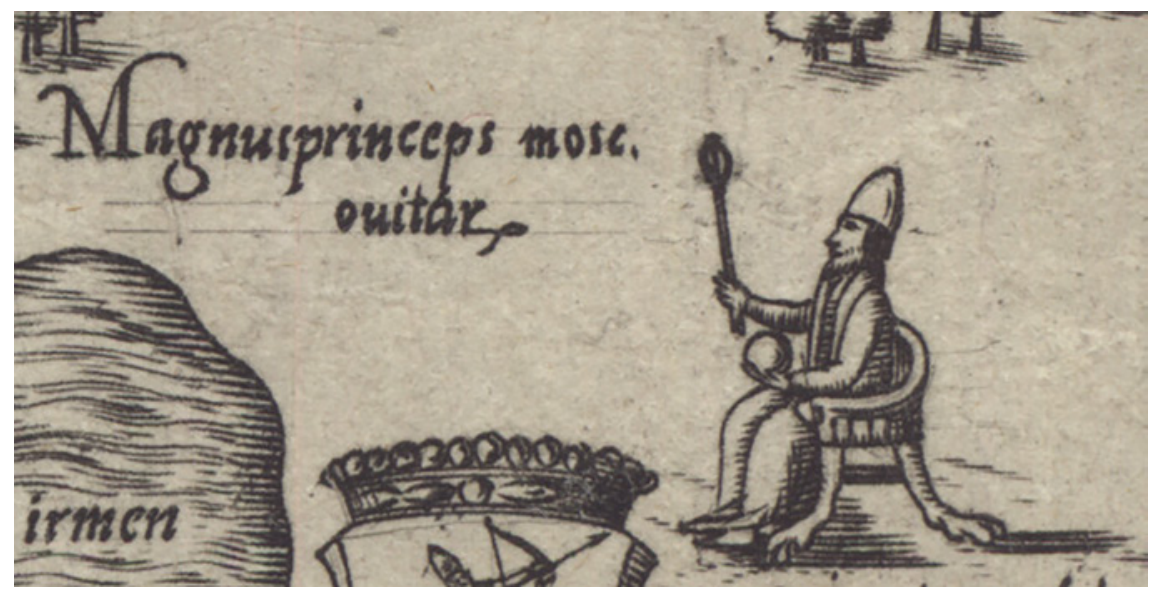

FIGURE 6 Great Prince of Muscovy (Olaus Magnus' Carta Marina, 1572)

1572 edition of the Carta Marina could work independently on the basis of the first edition of Magnus' map.

On the whole, in terms of artistic quality, the Muscovite royal image in the original Jenkinson map surpasses that in both editions of the Carta Marina. The artist of Jenkinson's map dramatized his representation of Ivan IV by placing him under a canopy with loosely folded drapery which provides a graceful and magnificent backdrop for the image of the tsar. The overall design of 
princely headgear in Magnus' and Jenkinson's maps is the same, but the creator of the latter has given the cap decorations which make it look like a tiara, somewhat similar to the cap of Ivan III in the World Cosmography by Andre Teve (1575). ${ }^{24}$

In addition to the royal image, the drawing in Jenkinson's map features a man standing in a bowed position in front of the tsar. Szykuła interprets the bowing figure as the English ambassador and one of the creators of the map, Anthony Jenkinson. ${ }^{25}$ However, there is nothing Western in that image. Rather, the man standing in front of Ivan IV's throne is dressed in long clothes of similar design and the same blue colour as the tsar's garments; the man's cap, which he holds in his left hand, is of the same conical shape as Ivan IV's headgear and the caps of Muscovites in Magnus' map, though not as lavishly decorated as the emperor's tiara; the man wears boots with curved toe-caps and without heels, very much similar to those that appear in Augustin Hirschvogel's engraved portrait of Vasilii III. ${ }^{26}$ The bowing figure obviously represents a Muscovite who is paying respect to his sovereign. It is also possible that the whole composition alludes to parallels between Muscovite Orthodoxy and Catholicism, a theme typical of English accounts of Muscovy. The bowing man looks at Ivan's feet, suggesting that he is going to kiss the tsar's shoe in the same way as Catholics kiss the Pope's shoe. In this respect one may note that Ivan's cap is highly reminiscent of the Pope's tiara.

The original Jenkinson map thus shows Ivan IV as a ruler venerated by his subjects. The image of the Muscovite ruler is very different from images of Muslim rulers which appear in other parts of the Jenkinson map. The Renaissance décor, Western royal regalia with a cross - all these elements represent the Muscovite tsar as a Christian ruler, who looks a bit "Popish" but generally very much similar to Western monarchs.

It is unclear whether Philip II ever saw this image of Ivan IV in the original Jenkinson map. Ortelius' atlas, which Philip had in his residence, includes a variant of Jenkinson's map which shows the tsar in a completely different manner (Fig. 7). ${ }^{27}$ Compositionally, the scene with Ivan IV in Ortelius' Theatrum has very little in common with the drawing in the original map. The atlas shows

24 On Teve's image, see S. N. Bogatyrev, "Shapka Monomakha i shlem naslednika. Reprezentatsiia vlasti i dinasticheskaia politika pri Vasilii II i Ivane Groznom," Peterburgskie slavianskie i balkanskie issledovaniia. Studia Slavica et Balcanica Petropolitana, 2011, no. 1 (9): 177 note 20.

25 Szykuła, "Anthony Jenkinson’s Unique Wall Map," 4.

26 On Hirschvogel's portrait, see Sergei Bogatyrev, "Bronze Tsars: Ivan the Terrible and Fedor Ivanovich in the Décor of Early Modern Guns," The Slavonic and East European Review, 88 (2010), 1/2: 55-57.

27 Online publication of the Ortelius variant of Jenkinson's map: https://kansalliskirjasto .finna.fi/Record/doria.10024_87766 (accessed 13 December 2019). 


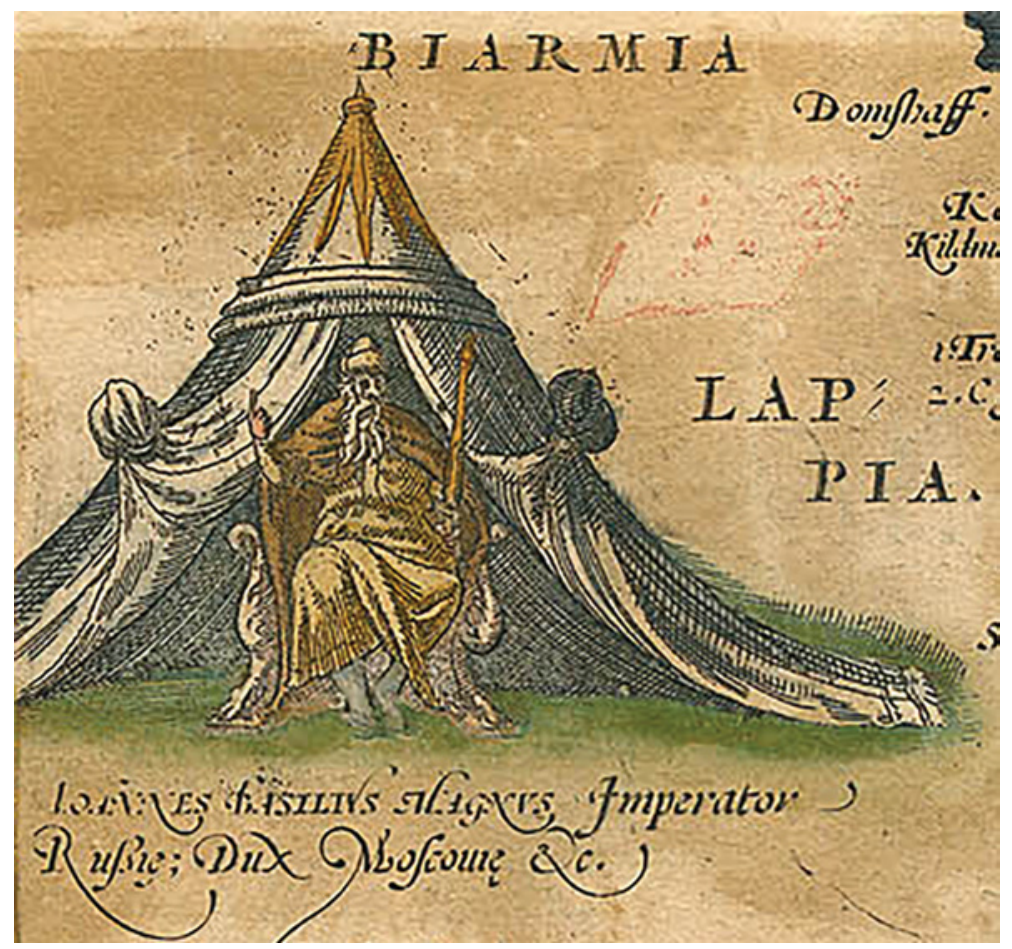

FIGURE 7 Ivan IV (Jenkinson map in Abraham Ortelius' Theatrum Orbis Terrarum, 1574)

the figure of Ivan depicted enface, and the figure of the bowing man is completely gone now. The symbolism of Ivan's power has also undergone profound revision. Ivan's headgear looks rather ineffective and does not resemble any recognizable symbol of royal or ecclesiastical authority. The tsar still has a sceptre in his left hand, but there is no orb in his right hand anymore; rather, his right hand points to the sky, perhaps an expression of his authority. Most importantly, the Renaissance drapery of the original map has been replaced with a tent with a golden top. This new backdrop is ideologically loaded because it echoes tents depicted in another part of the map which shows the territory of Tartaria. For the artist of the Ortelius variant of Jenkinson's map, tents were as typical symbols of the "Orient" as camels which appear in many parts of the map covering Tartaria and other areas between the $\mathrm{Ob}$ and the Caspian Sea as well as Persia. ${ }^{28}$ The figures of Muslim khans have also disappeared from the revised version of Jenkinson's maps, making it impossible for the viewer to compare and contrast the images of Ivan and Muslim rulers. Deprived of Christian symbols and placed in front of a Tatar tent, the image of 
Ivan IV in Ortelius' atlas is deliberately "oriental." Contrary to the representation of Ivan in the original map, the figure of the Russian tsar in the Ortelius atlas is completely different from depictions of Western Christian monarchs that we find in Western Renaissance cartography.

It was this exotic, non-Christian, "oriental" representation of Ivan IV that Philip II could easily observe in his residence at the Escorial. But his policies suggest that he did not buy this "orientalized" image of the Russian tsar. According to a French diplomatic account, Philip encouraged Ivan IV to attack the Ottoman sultan during negotiations with Osip Nepeia in London in 1557. When Ivan unleashed the Livonian war in 1558, Philip pleaded with him for the citizens of Narva and other Livonians, despite the Protestants' beliefs that it was Philip who instigated the tsar to attack Livonia. ${ }^{29}$ Philip returned to his plans of involving Muscovy in an anti-Turkish league after the death of Ivan IV. In 1585 , Philip's representative at the court of the Holy Roman emperor hosted the Russian ambassador L. Novosil'tsev. During the meeting the Spanish diplomat promoted the idea of a union between Christian monarchs against the Muslims, very much in line with what Philip expected from the Russian tsar as early as the 155 os. Philip's other activities relating to Russia were less proactive. His agents monitored Anglo-Russian commercial relations in the $1570 \mathrm{os}$. The king also had abortive plans to send a mission to Ivan IV in 1577 and to turn Ivan's successor on the Muscovite throne Fedor Ivanovich against the English. ${ }^{30}$

Ia. S. Lur'e believed that Philip II's attitude to Russia was driven by political rather than confessional reasons. He concluded that socially the feudal absolutist Spain was closer to Ivan closer to Ivan IV's political regime than the Netherlands and England were. However, Russian export of raw material to England and the Netherlands was strategically important and significantly helped these countries in their struggle against European (read Catholic, Habsburg, Spanish) reaction. ${ }^{31}$ We hardly need to follow this confused socio-political approach typical of Soviet historiography. Rather, it is more productive to explore the

29 Khoroshkevich, Rossiia, 223, 232; A. I. Filiushkin, Izobretaia pervuiu voinu Rossii i Evropu: Baltiiskie voiny vtoroi poloviny XVI v. glazami sovremennikov i potomkov (St. Petersburg: Dmitrii Bulanin, 2013), 613 .

3o Ia. S. Lur'e, "Russko-angliiskie otnosheniia i mezhdunarodnaia politika vtoroi poloviny XVI v.," in Mezhdunarodnye sviazi Rossii do XVII v. Sbornik statei, ed. A. A. Zimin, V. T. Pashuto (Moscow: Izdatel'stvo AN sssR, 1961), 428, 434-435. See also Zimin, V kanun, 186-187.

31 Ia. S. Lur'e, "Katolicheskaia reaktsiia i podgotovka interventsii protiv Russkogo gosudarstva (konets XVI - nachalo XVII v.)," in Voprosy religii i religiovedeniia, issue 4, book 1 (Moscow: MediaProm, 2010), part 1: 246 (first published in 1957); Lur'e, "Russko-angliiskie otnosheniia," 442-443. 
relations between Ivan and Philip from the perspective of their religiosity following the comparative mode of analysis offered by Cherniavsky and Halperin. If one tries to visualise Philip II's attitude to Ivan IV, the best illustration of it would be the image of the tsar in the original Jenkinson map, even if we have no evidence that Philip ever saw that representation. Philip II obviously perceived the Russian tsar as a powerful Christian monarch. The Muscovite perception of the Habsburg king was reciprocal. The manifestations of religiosity in domestic politics reveal more common traits shared by Ivan and Philip.

\section{2}

\section{Religiosity}

Among sixteenth-century monarchs, Ivan IV and Philip II stand out for their intensive, if not fanatical religious beliefs. The personal spaces of both monarchs were infused with religious symbolism. Simultaneously with the establishment of the Oprichnina, Ivan commissioned his tomb in the Archangel Cathedral in the Kremlin (1564-5). The location of the tomb is most unusual as it is beyond the altar, i.e. in the most sacred part of the cathedral. Philip organised his space in a similar manner by arranging his bedroom and study in the proximity of the altar of the colossal Basilica at the Escorial. ${ }^{32}$ Both places reveal a personal, even possessive attitude to God. Each in their own way, Ivan and Philip were saying: "this is my God, do not step between me and my God."

The location of Philip's private rooms at the Escorial leads us to a broader subject: Ivan's and Philip's obsession with their countryside residences, Aleksandrovskaia Sloboda and the Escorial. Countryside residences freed rulers from the constraints of official religion and offered them new ways for expressing their religiosity. The first ruler to create a new residence for a new cult was probably Amenhotep IV (Akhenaten), who founded a new capital, Amarna, in the desolate plain of Middle Egypt in ca. 1347 BC to celebrate the solar cult of Aten. Accidently, Aleksandrovskaia Sloboda and the Escorial came to prominence almost simultaneously. Established in 1513, Sloboda became the capital of the Oprichnina in 1564 while the foundation stone of the Escorial was laid in

32 Ivan's tomb: T. E. Samoilova, T. D. Panova, The Burial Chamber of Ivan the Terrible (Moscow: The Moscow Kremlin, 2004); Philip's private quarters: Kubler, Building the Escorial, 87-89. Halperin also mentions a personal chamber designed for Ivan in the Annunciation cathedral after his fourth marriage in 1572 (249), but the association of the chamber with Ivan is an urban legend. See A. L. Batalov, "O datirovke belokamennoi rez'by na iuzhnoi paperti Blagoveshchenskogo sobora," in Tsarskii khram. Blagoveshchenskii sobor Moskovskogo Kremlia v istorii russkoi kul'tury (Materialy i issledovaniia 19, Moskovskii Kreml', Moscow: Kuna, 2008), 330-354. 
1563. Both residences had common functions. First of all, they served as countryside palaces for their masters. What is important that both also housed religious institutions. ${ }^{33}$ Philip II rigorously observed the feasts of the Hieronymite Order at his residence. He used the religious ceremonies at the Escorial to demonstrate his modesty and piety, for example, by choosing the south-western corner seat of the choir rather than the prestigious prior's seat or the impressive seats that flanked it. ${ }^{34}$

Ivan IV went even further than Philip. At Aleksandrovskaia Sloboda, the tsar assumed the functions of an abbot while other high-ranking courtiers (senators, according to Albert Schlichting) acted as monks. All members of that brotherhood, including Ivan, wore similar dark habits with a cowl. The practice of this court religious institution included joint prayers and communal meals, attendance to both was compulsory, and addressing every member of that religious community, including the tsar, brother. ${ }^{35}$ The religious practices of this brotherhood offered an egalitarian alternative to the traditional hierarchy of the Muscovite court.

Religious ceremonies were of course typical of every pre-modern court. However, Ivan and Philip gave a new dimension to these ceremonies by shifting their focus to their countryside residences. The religious rituals practiced at Sloboda and the Escorial at least partially served as compensatory and explanatory mechanisms for the use of violence in pre-modern politics. Ivan performed religious rites at his cloister for several days after which he returned to public life, which undoubtedly included terror and executions. We can detect a similar pattern in Philip II's behaviour. As Geoffrey Parker notes, "numerous religious activities allowed the king to step back from the constant stress of having to take decisions and renewed his ability to cope with broader issues." By the stress of decisions Parker means, among other things, the need to rationalise the arrests of the king's son Don Carlos (1568) and Secretary of State Antonio Pérez (1579). After both arrests Philip retreated to the Escorial where

33 There was also a library, a mausoleum, a college, a seminary and a hospital at the Escorial. Sloboda certainly housed a collection of books and documents required for the functioning of the local scriptorium and press, as well as for Ivan's court administration. While at Sloboda, Ivan requested to send him diplomatic records, decisions on precedence disputes, a description of his coronation as tsar, a chronicle and additional material for it. S. O. Shmidt, ed., Opisi Tsarskogo arkhiva XVI veka i arkhiva Posol'skogo prikaza 1614 goda (Moscow: Izdatel'stvo vostochnoi literatury, 196o), 19, 35, 36, 39, 43. There is no evidence of any memorial and medical establishments or educational bodies intended for students at Sloboda.

34 Rosemarie Mulcahy, The Decoration of the Royal Basilica of El Escorial (Cambridge: Cambridge University Press, 1994), 9.

35 [Albert Schlichting], "A Brief Account of the Character and Brutal Rule of Vasil'evich, Tyrant of Muscovy," Canadian-American Slavic Studies, 9 (1975), 2: 232. 


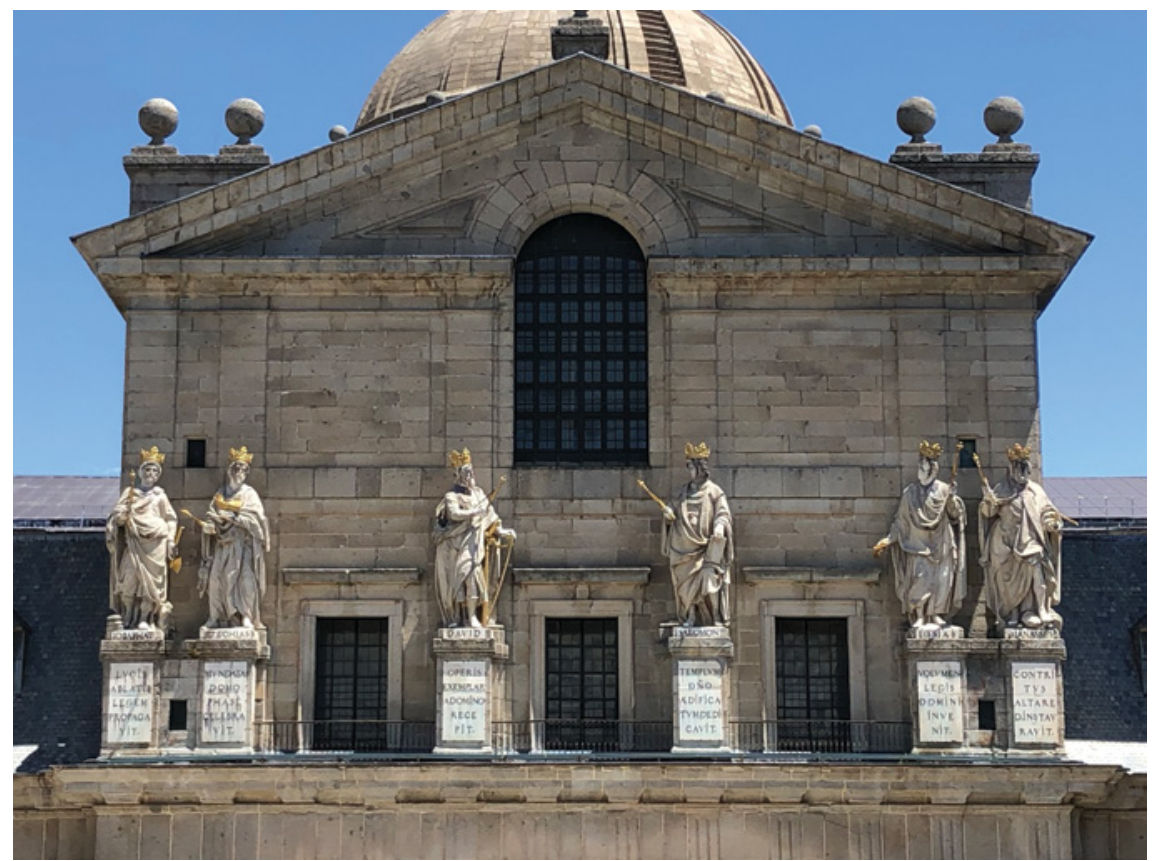

FIGURE 8 Kings of Israel at the portico of the Basilica, the Escorial (photo by the author)

he confessed and took communion in the royal chapel. ${ }^{36}$ The king's confession undoubtedly included Philip's own explanation of his actions to God.

Rigorous religious practices marked the countryside residences of Ivan and Philip as sacred places. Constant prayers invited comparison between the Escorial and Ancient Israel with its Temple of Solomon, and by extension, with Heavenly Jerusalem and the Heavenly Court. Such parallels were enhanced by the statues of six kings of Israel at the portico of the Basilica (Fig. 8), the pictorial programme of the chapel, and illumination, which decorated the Escorial on feast days. ${ }^{37}$

The themes of Jerusalem, both terrestrial and Heavenly, and the Apocalypse became very prominent in Muscovite court culture in the late 1550 s and the 1560 s, i.e. on the eve of Ivan's departure to Sloboda and during the Oprichnina. Examples include Ivan's banner with apocalyptic imagery (1559/6o), a chapel dedicated to the Entry into Jerusalem at Ivan's court church in the Kremlin

36 Geoffrey Parker, Imprudent King: A New Life of Philip II (New Haven, London: Yale University Press, 2015), 82.

37 Francis Xavier Rocca, Cloister and Court: The Escorial and Philip II of Spain (PhD diss., Yale University, 1998), 10; Mulcahy, Decoration, 78. 
(the Annunciation cathedral, 1566), Ivan's Oprichnina court in Moscow which was fashioned after the description of Heavenly Jerusalem in the Book of Ezekiel, and, most likely, the icon Church Militant, which I date to the early 1560 s. $^{38}$

The decorative programme of the churches at Aleksandrovskaia Sloboda also contains references to eschatological themes associated with the beginning and end of Christian history. The history of church construction and decoration at Sloboda is very complex. Unlike the Escorial, which was created according to one uniform plan, Sloboda underwent a series of renovations in the sixteenth and seventeenth centuries. Among the Sloboda churches, the Trinity church is particularly important as it was part of Ivan's palace (Fig. 9). ${ }^{39}$ Its frescoes, which date to the 1560 or oarly 1570 s, focus on figures that symbolise two opposite ends of world Christian history. On the one hand, the frescos depict the Biblical forefathers Abraham, Isaiah and Jacob who made covenants with God. On the other hand, the frescoes of the Trinity at Sloboda include characters representing what East Slavic literati described as the almost final, eleventh hour of Christian history, i.e. the conversion of Rus': Kyivan royal saints and ancestors of Ivan IV SS Vladimir and his sons Boris and Gleb.

Philip established the Escorial as a showcase of orthodoxy at a time of religious crisis in the Christian world. ${ }^{40}$ This orthodoxy, expressed in what Philip considered iconographic correctness, caused him to reject El Greco's Martyrdom of St Maurice as well as some works of Titian and other masters. ${ }^{41}$ The imagery of the Trinity church also rejected the newest tendencies in Muscovite court art. The minimalistic selection of saints in the Trinity's frescoes was in striking contrast with other sixteenth-century decorative programmes which were becoming increasingly complex and detailed. By focusing on the earliest

38 Sergei Bogatyrev, "The Heavenly Host and the Sword of Truth: Apocalyptic Imagery in Ivan IV's Muscovy," in The New Muscovite Cultural History: A Collection in Honor of Daniel B. Rowland, ed. Valerie Kivelson and others (Bloomington, Ind.: Slavica Publishers, 2009), 77-90; A. L. Iurganov, Kategorii russkoi srednevekovoi kul'tury (Moscow: MIRos, 1998), 382-393; I. Ia. Kachalova, "Tsarskii khram," in Tsarskii khram: Sviatyni Blagoveshchenskogo sobora v Kremle, ed. M. V. Vilkova and others (Moscow: Maksim Svetlanov, 2003), 18; S. N. Bogatyrev, “Tsarskaia vlast' v 1550-e gody: Preemstvennost' ili novatsii?" in Reprezentatsiia vlasti $v$ posol'skom tseremoniale i diplomaticheskii dialog $v X V-$ pervoi treti XVIII $v e k a$, ed. A. K. Levykin and others (Moscow: Gos. istoriko-kul'turnyi muzei-zapovednik "Moskovskii Kreml," 2006), 19-20.

39 V. D. Sarab'ianov, "Programma rospisi Pokrovskogo shatra Aleksandrovskoi slobody," in Aleksandrovskaia sloboda: Materialy nauchno-prakticheskoi konferentsii, ed. S. A. Gleibman (Vladimir: Zolotye vorota, 1995), 39-53. The Trinity church was later rededicated to the Intercession (Pokrov).

40 Rocca, Cloister, 180.

41 Mulcahy, Decoration, 54-67. 


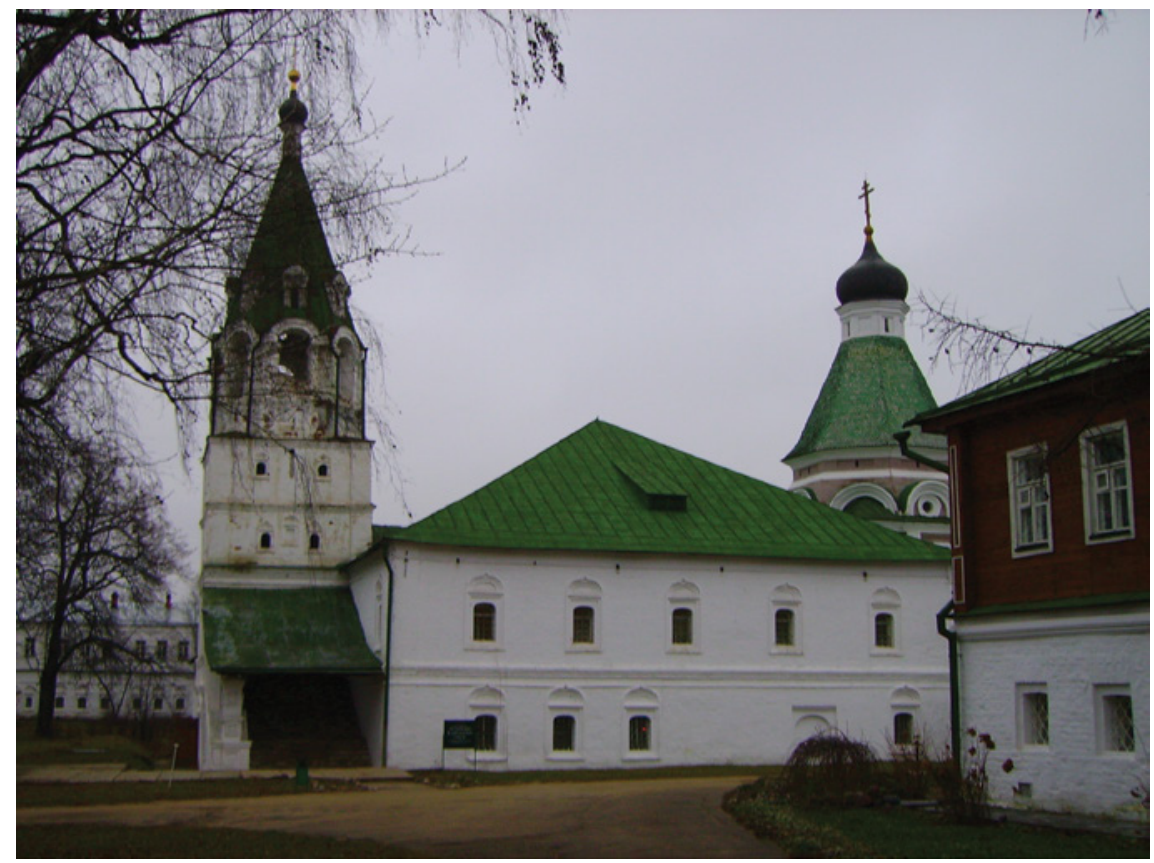

FIGURE 9 Trinity church (now the church of the Intercession), the tent roof with frescoes is on the right, Aleksandrovskaia Sloboda (photo by Nikolai Bogatyrev)

forefathers of Ancient Israel and the founding figures of East Slavic royal holiness, the programme of the Trinity church created an eschatological image of Muscovy as the ultimate successor of Ancient Israel and, by extension, Ivan as the successor of Biblical and Kyivan forefathers.

Intensive religiosity practiced at Sloboda and the Escorial manifested itself not only in ritual and decorative programmes but also in collecting relics. When Ivan left Moscow for Sloboda, he took along the most revered icons, crosses adorned with gold and precious stones, gold and silver vessels and sideboards. ${ }^{42}$ During the punitive expedition against Novgorod, Ivan also confiscated numerous icons, books and bells. Among the booty taken in Novgorod was one pair of fourteenth-century gates with religious images from the St. Sophia. ${ }^{43}$ These Novgorodian gates were installed in the main cathedral of Sloboda.

42 Ruslan G. Skrynnikov, Reign of Terror: Ivan IV, transl. Paul Williams (Leiden, Boston: Brill, 2016), 211.

43 May be even two pairs of gates, see L. I. Livshits, "K voprosu o proiskhozhdenii i vremeni sozdaniia 'Tverskikh vorot' Aleksandrovskoi slobody," in Aleksandrovskaia Sloboda, 102-111. 
The Escorial is famous for its collection of some 7,500 relics, which Philip II inherited, received as gifts, or acquired through agents, including those operating in Protestant countries. ${ }^{44}$ As far as I know, no relics were taken by force. Philip not only collected relics but also disseminated them. For instance, he gave the city of Cartagena some relics of local saints that he had purchased on another occasion. ${ }^{45}$ Similarly, after the confiscation of vessels in Moscow, Ivan eventually returned the silver ones. He also made restitution by returning some confiscated icons to Novgorod (icons of Apostles Peter and Paul) and ordered a copy of another looted icon (Saviour) be made for Novgorod. ${ }^{46}$ Such actions may look like erratic inconsistency or attempts at reconciliation. Scholars often argue that both types of behaviour were typical of Ivan. However, studies of Philip's attitude to relics offer a new perspective on Ivan's motives. Guy Lazure explains that the Spanish king was eager to demonstrate that relics first and foremost belonged to him: it was he who graciously agreed to turn over relics to a city or prelates. The collection of relics served to establish Philip's authority as a Christian ruler and helped him project a coherent image of himself and his monarchy to contemporaries and to posterity. By reserving rights to relics from every church in his kingdom for his own private collection, Philip II asserted and reaffirmed his personal authority. ${ }^{47}$

I think Ivan was driven by similar aspirations to establish his ultimate authority over religious objects. This explains why, together with returning Novgorodian icons to the city, he also sent to Novgorod a copy of the Vladimir Mother of God and commissioned a royal pew for the Novgorodian St. Sophia Cathedral (1571). Both objects referred to Muscovite Orthodoxy: the Vladimir Mother of God was of course the most venerated icon in Moscow, whereas the pew obviously echoed the tsar's roofed throne in the Dormition Cathedral in the Moscow Kremlin. ${ }^{48}$ The message was clear: it was Ivan who decided what icons the Novgorodians could keep and what Muscovite patterns they should follow. Both Philip and Ivan affirmed their royal prerogatives by confiscating and distributing relics. Each of them saved relics from enemies, Philip from the Protestants and Ivan from the alleged traitors in Moscow and Novgorod. And each of them returned the saved relics to those who deserved them.

At some point, both Ivan and Philip turned to world history. The Spanish king commissioned a history from the royal chronicler Antonio Herrera whose

44 Mulcahy, Decoration, 105.

45 Guy Lazure, "Possessing the Sacred: Monarchy and Identity in Philip II's Relic Collection at the Escorial," Renaissance Quarterly, 60 (2007), 1: 80.

46 Mariia Makhan'ko, Pochitanie $i$ sobiranie drevnikh ikon v istorii $i$ kul'ture Moskovskoi Rusi XVI veka (Moscow: BuksMArt, 2015), 65.

47 Lazure, "Possessing," $58-93$.

48 Makhan'ko, Pochitanie, 65. 
General History of the World in the Age of Philip II, the Prudent began in $1559 .{ }^{49}$ Such limited coverage would not be enough for Ivan. As we saw, the frescoes of the court Trinity church presented a streamlined version of world history from the images of Old Testament forefathers to the ancestors of Ivan IV. Similar approach to history informed the most ambitious chronicle ever produced in Rus', the above-mentioned Illustrated Chronicle Compilation. This gigantic chronicle contains about 10,000 folios and 17,000 miniatures, covering the period from the Creation through Roman and Byzantine history to the history of the East Slavs and culminating, naturally, in the reign of Ivan IV.

The creation of the chronicle and other cultural activities at Sloboda show that it was not just "a bloodthirsty town," the capital of the Oprichnina terror, but also a cultural centre with an active scriptorium and a press. In his review of a work on Muscovite book culture, Halperin comments on a book copied at Sloboda: "Considering the executions and torture taking place there (at Sloboda - SB), one wonders how conducive the atmosphere was to copying a manuscript book. ${ }^{n 0}$ The cultural output of chroniclers, scribes and artists working at Sloboda suggests that the atmosphere was conducive despite the terror.

Typological parallels between Sloboda and the Escorial reveal important aspects of the Oprichnina. A comparative analysis of Ivan IV and Philip II suggests that we should be careful with some of Cherniavsky's assertions about Ivan. In his explanation of the Oprichnina Halperin develops Cherniavsky's idea that Ivan was experiencing what Cherniavsky called "enormous ideological escalation" (212). According to Halperin, Ivan established the Oprichnina because of his "ideological overload" (214). The most burdensome element of Muscovite royal ideology was the title of tsar. As Cherniavsky and other scholars have demonstrated, the title had multiple religious and political layers, as it was applied to such different rulers as the Byzantine emperor and the Mongol khan and also to Christ. Ivan's coronation as tsar added tension to his relations with the Polish king who interpreted the title as a Muscovite imperial claim. If Ivan really wanted a relief, he should have dropped the title of tsar. But he never did that. Furthermore, Ivan deprived a Chinggisid (Simeon Bekbulatovich) of that title, thereby eliminating possible contenders for the title. ${ }^{51}$ Contrary to Cherniavsky and Halperin, the fact that Ivan always kept the title of tsar indicates that he never abdicated, though he could entrust parts of his

49 Parker, Imprudent King, xviii, 384 no. 3.

50 Charles J. Halperin, "'Do Not Curse Me for My Copying Errors: Sixteenth-Century Russian Manuscript Books," Russian History, 46 (2019), no. 2-3: 163.

51 Sergei Bogatyrev, "Ivan IV (1533-1584)," in The Cambridge History of Russia. Volume 1: From Early Rus' to 1689, ed. Maureen Perrie (Cambridge: Cambridge University Press, 2006), 261 (errata: Ivan gave Simeon the title of grand prince of all Rus', not that of Moscow). 
patrimony, including Moscow, to other people on a temporary basis, as it happened during the Oprichnina and the "reign" of Simeon Bekbulatovich (cf. 73, $166,178,213,214)$.

Like Philip, Ivan was driven not by ideological overload, but rather by religious considerations, by his aspiration for original, simple, correct Christianity, an idea which was central to the cultural programmes of Sloboda and the Escorial. Despite obvious confessional, aesthetic and political differences, both programmes focused at rediscovering the origins of Christian faith and emphasised direct connections between the foundation Christian myth and contemporary monarchs, Philip and Ivan respectively. This is why both rulers resorted to the same spatial and functional model, a countryside palacemonastery, which freed them from the constraints of established religious and court institutions.

Countryside residences did help monarchs relieve the stress of decision making. But Philip did not create anything similar to the Oprichnina at the Escorial. Neither did Ivan IV's father Vasilii III when he established Aleksandrovskaia Sloboda as his residence in 1513. What was special about Ivan IV's attitude to Aleksandrovskaia Sloboda was that is provided him security, as he suspected his old court and clerics of high treason. Ivan's preoccupation with security led to terror, and no study of Ivan the Terrible can ignore the Oprichnina executions at Sloboda. However, Halperin reminds us that other aspects of the Oprichnina should be taken as seriously as terror. He rejects the semiotic interpretation of the Oprichnina brotherhood as a parody of the established church because the brothers rigorously observed church services at Sloboda (185). Indeed, Ivan did not joke about his religion. Neither did Philip or any other contemporary Christian ruler, whether Catholic or Protestant. Halperin's comparative methodology helps us understand Ivan the Terrible in the global context of sixteenth-century Christianity.

\section{Acknowledgements}

I presented aspects of this paper in my talks at the international conference "From the Scriptorium to the Library," IE University, Segovia (Spain), 10-12 June, 2019 and the round table on Charles J. Halperin, Ivan the Terrible: Free to Reward and Free to Punish (Pittsburgh, Pa.: University of Pittsburgh Press, 2019) at the 2019 Convention of the Association for Slavic, East European, and Eurasian Studies (San Francisco, CA, 23-26 November 2019). I would like to thank Prof. Susana Torres Prieto (IE University), who organised the Segovia conference, and Prof. David Goldfrank (Georgetown University), the organiser 
of the roundtable in San-Francisco, for inviting me to participate in their events. Prof. Torres was also instrumental in organising my visit to the Escorial. I am grateful to José Luis del Valle Merino, Director of the Royal Library at the Escorial for information on the library's holdings. Almudena Pérez de Tudela Gabaldón, curator of the Royal Monastery of the Escorial, kindly explained the history of maps hanging in the Escorial's Galería de Paseo. Many thanks to Prof. Valerie Kivelson (University of Michigan) for references to works on Jenkinson's map of Russia. 